\title{
Tramas do outro nas telas do discurso: circulação audiovisual e consumo cultural
}

\section{Tramas del otro en las pantallas del discurso: circulación audiovisual y consumo cultural}

\author{
Networks of the other on discursive screens: \\ audiovisual circulation and cultural consumption
}

\author{
Rosana Soares ${ }^{1}$ \\ Andrea Limberto ${ }^{2}$
}

Palavras chave:

Políticas da representação

Regimes de visibilidade

Figuras de alteridade

Discursos audiovisuais

Consumo cultural
Resumo:

O artigo analisa articulações discursivas em torno da questão da invisibilidade social, notadamente em documentários brasileiros recentes (Elena, Cidade cinza, Olhe pra mim de novo), exibidos em circuito comercial e que, privilegiando uma abordagem referencial e de cunho realista, apresentam certos atores sociais como pertencentes a essa condição. O empenho realista interessa-nos por operar um movimento de afirmação dos sujeitos representados, aprovando-os como se eles fossem, no âmbito do filme e no âmbito da vida, exatamente como mostrados nos filmes.Este tem sido um desafio teórico para os estudos fílmicos desde o estabelecimento da noção de uma sintaxe do visível. Ainda que exista uma barreira lógica para a representação de sujeitos em situação de invisibilidade, isso de nenhum modo tem impedido que ela seja tematizada frequentemente pelo discurso cinematográfico. Tampouco tem impossibilitado que certas políticas da representação operem como marcas sobre determinados sujeitos, supostamente periféricos, atuando como estandartes de identidades minoritárias nos modos de tornarem-se visíveis em cena. 


\section{Resumen:}

El texto analisa las articulaciones discursivas vinculadas al problema de la invisibilidad social, especialmente en recientes películas documentales brasilenãs (Elena, Cidade cinza, Olhe pra mim de novo). Proyectadasen circuito comercial favorecen un enfoque referencial, de perspectiva realista y nos presentan actores sociales que pertenecen a esa situación. El diseño realista interésanos porque opera un movimiento de afirmación de los sujetos ahí representados, aprobándola como si fuera en el ámbito del video y en el de la vida, exactamente como mostrado en la película. Esto es un desafío teórico para los estudios de cine desde que se articuló la noción de sintaxis del visible. Aun que haya un obstáculo lógico a la representación de los sujetos en situación de invisibilidad, eso no ha impedido, de ninguna manera, que sea tema frecuente en el discurso cinematográfico. Tampoco previene que ciertas políticas de representación operen como marcas sobre sujetos supuestamente periféricos. Estos actúan como estandartes de identidades minoritarias por la manera que se hacen visibles en la escena.

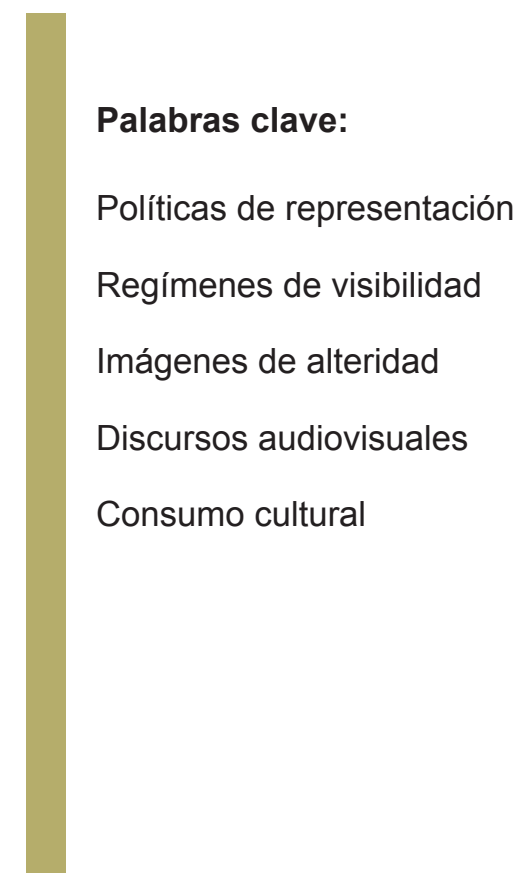

\section{Keywords:}

Politics of representation

Regimes of visibility

Images of alterity

Audiovisual discourses

Cultural consumption

\section{Abstract:}

The article analyzes discursive articulations regarding the matter of social invisibility as it especially considers recent Brazilian documentary films (Elena, Cidade cinza, Olhe pra mim de novo). Those were in the exhibition circuit and privilege a referential and realistic approach presenting some social actors that fit the invisibility condition. We are interested in the realistic drive on movies as it is able to perform anaffirmative reaction by the subjects involved. The narrative is build as if the facts were in life and in the movies just like shown on screen. Such has been a theoretical challenge for film studies since the establishment of the notion of syntax of the visible. Even if one can recognize the logical distance for the representation of individuals in situation of invisibility, that has not prevented them from being present in audiovisual discourses. Neither has it stopped certain politics of representation to operate as a stamp over a certain kind of subject presented as minority identities. 
Tramas do outro nas telas do discurso: circulação audiovisual e consumo cultural

O artigo propõe uma análise do discurso cinematográfico a fim de apontar possíveis articulações em torno da questão da invisibilidade social. Este tem sido um desafio teórico para os estudos fílmicos desde o estabelecimento, por contraponto, da noção de uma sintaxe do visível (cf. METZ, 1972; AUMONT, 1995). Assumimos que exista uma barreira lógica para a representação de sujeitos em situação de invisibilidade, o que de modo algum tem impedido que ela seja tematizada frequentemente em filmes. Ou ainda, que opere como uma marca sobre determinados sujeitos em cena, periféricos, atuando como estandartes de identidades minoritárias nos modos de tornarem-se visíveis.

Ao mesmo tempo, não podemos deixar de ressaltar a aparição poética desses mesmos sujeitos como estando em uma posição política - e dizemos, com Nichols(1991), que se trata também de uma imagem ideológica -, ambas associadas numa forma de representar. Entendemos, ainda, acompanhando o pensamento de Rancière $(1996 ; 2005)$, que a criação na linguagem implica, invariavelmente, um engajamento poético e uma representação política.

Observamos, num aparente paradoxo, que identidades consideradas minoritárias têm tido espaço para a construção de seus modos de representação em discursos audiovisuais (notadamente em filmes baseados em acontecimentos que tematizam a periferia, o crime, a violência, a homossexualidade, o racismo, as questões de gênero etc.) assumindo, desse modo, um espaço de visibilidade. Independentemente, identificamos a invisibilidade como uma dimensão fundamental na maneira como os processos de representação se apropriam desses sujeitos.

\section{Desenho do visível por meio da marca documental}

Ao tratarmos de novas políticas da representação, voltamo-nos, principalmente, para o campo da produção e da circulação de discursos. Entretanto, quando observamos as práticas midiáticas não podemos deixar de considerar a questão da recepção, ou seja, do consumo cultural em suas múltiplas formas. Novos atores sociais entram em cena para compor, de modo complexo, tramas narrativas que contemplem, ao mesmo tempo, os desafios da sociedade contemporânea organizada em rede e as demandas dos sujeitos em suas diferentes posições. Como afirma De Certeau (1996), a relação entre estratégias e táticas imprime novas relações de força entre os diversos sujeitos, possibilitando deslocamentos e o contorno de outros cenários culturais na busca por afirmações identitárias alternativas:

Chamo de estratégia o cálculo (ou a manipulação) das relações de forças que se torna possível a partir do momento em que um sujeito de querer e poder (uma empresa, um exército, uma cidade, uma instituição científica) pode ser isolado. A estratégia postula um lugar suscetível de ser circunscrito como algo próprio e ser a base de onde se podem gerir as relações com uma exterioridade de alvos ou ameaças (os clientes ou os concorrentes, os inimigos, o campo em torno da cidade, os objetivos e objetos de pesquisa etc.) (DE CERTEAU, 1996, p. 99).

No campo da produção audiovisual, práticas de consumo recentes provocam e são provocadas pela revitalização do gênero documental na última década, quando vemos a propagação de filmes que se 
dirigem a novas audiências e, ao mesmo tempo, retratam outros agentes sociais, ampliando o campo do visível e, consequentemente, os regimes de visibilidade nele presentes. Em sua definição mais geral, ou seja, filmes que retratam o mundo concreto por meio de escolhas técnicas, estéticas e narrativas visando contar determinadas histórias para uma audiência específica, os documentários encontram no público o espaço de construção de interpretações, remetendo suas formas discursivas àquilo convencionado como realidade. $A$ relação com a realidade estabelece, ainda, outro pacto, qual seja, o compromisso dos documentários com a suposta verdade dos fatos encenados, escamoteando, muitas vezes, as estratégias de sua fabulação. $\mathrm{Na}$ relação entre produção e recepção, ainda que se espere que os documentários contem histórias verdadeiras sobre o "mundo real", tal expectativa pertence, ela mesma, ao pacto de leitura estabelecido:

Não se espera que tais histórias sejam contadas de modo objetivo, tampouco que sejam completamente verdadeiras. O realizador pode se valer, ocasionalmente, do uso de licença poética no relato e se referir simbolicamen te à realidade. (...) Mas espera-se que os documentários sejam uma representação justa e honesta de uma experiência vivida por alguém (AUFDERHEIDE, 2007, p. 3, tradução nossa).

É na interface entre o repertório do público, seu interesse pelos fatos narrados e a maneira como os realizadores apresentam tais fatos que se estabelece um intervalo no qual vislumbrar possíveis efeitos de sentido a partir dos filmes. De certo modo, não há regras extrínsecas ao filme documentário que possam defini-lo enquanto tal, apenas escolhas que dizem respeito a como tecer suas narrativas de modo a torná-las consistentes e credíveis em relação aos contratos comunicacionais selados com a audiência. Um novo aspecto soma-se a esse pacto, incluindo na tessitura dos documentários questões relacionadas ao mercado de produção e distribuição de filmes, que se encontra com as possibilidades de divulgação e apropriação dos mesmos. À medida que os documentários passam a ocupar espaços ampliados no circuito audiovisual, sua definição enquanto gênero discursivo específico também se fortalece, não apenas no cinema como também na televisão e na internet, especialmente se considerarmos as mídias digitais e os aparatos móveis utilizados para sua propagação.

Como representação expressiva das tensões e contradições nas práticas socioculturais contemporâneas, o cinema convida ao deleite e também à reflexão. De fato, o espectador que se dispõe a compor sua sensibilidade com o fluxo imagético na tela e imergir na narrativa ficcional do filme que está assistindo terá a oportunidade de interagir - e mesmo de desvelar - outras visões de mundo, vivenciando de um tipo de experiência que poderá levá-lo a pensar e atribuir sentido às questões de nosso tempo a partir de novas perspectivas (CASTRO, 2013, p. 2).

Por meio da inserção dos documentários como integrantes da dinâmica de consumo cultural, portanto, buscamos apontar os modos de estabelecimento de vínculos sociais na contemporaneidade, visando a problematização das formas de construção de identidades, subjetividades e sociabilidades presentes nas interações cotidianas. É assim que cenários em constante transformação geram práticas e usos diferenciados em termos de consumo cultural midiático, possibilitando a realização de documentários que, para além de sua vocação original, ampliam as possibilidades de representação do outro, tornando-o mais radical em sua alteridade, menos domesticado em relação àquilo estabelecido como normatização ou normalização social: 
A realidade não é algo que esteja lá fora, mas aquilo que conhecemos, entendemos e compartilhamos uns com os outros sobre o que está lá fora. As mídias interferem na realidade mais valiosa que existe, aquela que está em nossas mentes. Documentários são uma importante forma de comunicação e formatação da realidade, justamente por evocaram a verdade. Eles são sempre fundados na realidade e pretendem nos contar alguma coisa que valha a pena ser conhecida (AUFDERHEIDE, 2007, p. 5 , tradução nossa).

É um extremo que vemos surgir, muitas vezes, nas telas de cinema, trazendo à tona novos regimes de visibilidade que alargam as políticas da representação usualmente aceitas. Como assinalamos anteriormente (SOARES, 2011, p. 144), Bakhtin (1987) estabelecera relações entre uma estética do grotesco e modos de ressignificação cultural que subvertem antigas oposições, instaurando formas de comunicação em que normas e barreiras sociais são temporariamente suspensas, violando regras habituais da vida coletiva, como nos festejos populares do carnaval. Para o autor, "o exagero, o hiperbolismo, a profusão, o excesso são, segundo opinião geral, os sinais característicos mais marcantes do estilo grotesco" (BAKHTIN, 1987, p. 265).

A circulação de documentários que tematizam de alguma forma a invisibilidade, as identidades minoritárias, os estigmatizados já aponta para o alargamento nas trocas de bens simbólicos, em que a invisibilidade se torna um modo de inserção social e mercadológica. Essa circulação está relacionada à acumulação de capital, material ou simbólico, que pode reverter em recursos financeiros e reconhecimento pessoal tanto para documentaristas como para personagens. A proliferação de imagens em páginas da internet, seja com vídeos no YouTube, perfis em redes sociais como Facebook e Twitter, ou trailers oficiais em sites corrobora as análises, apontando para o caráter expansivo do consumo na atualidade. Um duplo movimento, então, apresenta-se como eixo articulador dessa perspectiva: se por um lado vemos aumentarem as possibilidades de tornar visíveis sujeitos antes obscurecidos, por outro vemos surgirem, cada vez mais, imagens que se conformam à ordem visual vigente, especialmente aquelas destacadas: discursos de cunho realista dirigidos ao estabelecimento de verdades sobre fatos narrados.

Em Testemunha ocular (2004), Peter Burke tematiza a questão da objetividade e da fidelidade na representação dos fatos por meio da análise de imagens fotográficas, questionando-as enquanto provas de evidência histórica. Dentre os vários conceitos trazidos, o autor apresenta uma série de problemas advindos da crença na autenticidade e veracidade das imagens fotográficas: o problema das fotografias fabricadas, dos interesses daqueles que as encomendam, de pressões externas (editores, veículos). Segundo o autor, o conceito de "testemunha ocular" - alguém capaz de fielmente "representar o que, e somente o que, poderia ter visto de um ponto específico num dado momento" (BURKE, 2004, p. 18) - reforça a crença na possibilidade de um testemunho preciso e verdadeiro, esquecendo as diferenças sempre presentes tanto no que os discursos (verbais ou visuais) deixam transparecer, como naquilo que ocultam.

Notamos na produção cinematográfica recente um conjunto de filmes, ficcionais ou documentais, que problematizam de modo singular a questão da objetividade nos relatos e da fidelidade aos fatos. Entre eles, destacamos produções iranianas e brasileiras: os filmes iranianos Salve o cinema (Mohsen Makhmalbaf, 1995), Cópia fiel (Abbas Kiarostami, 2010) e Isto não é um filme (Mojtaba Mirtahmasb 
\& Jafar Panahi, 2010); e os documentários brasileiros Jogo de cena (2007), Moscou (2009) e As canções (2011), últimos filmes realizados por Eduardo Coutinho ${ }^{3}$. Ainda que reconheçamos a variedade estética, técnica e estilística de cada um desses filmes, apontamos algumas das articulações discursivas presentes em suas narrativas, notadamente híbridas e cambiantes.

Já na década de 1990, Salve o cinema, como outros filmes iranianos, mescla encenação e registro em suas imagens, numa espécie de ficção documental na qual o diretor convoca possíveis atores, por meio de um anúncio de jornal, a realizarem testes para seu próximo filme. Makhmalbaf filma os testes e, ao ser interpelado sobre quando teriam início as filmagens com os escolhidos, responde que o filme havia acabado de ser realizado. Na ficção Cópia fiel (no original, cópia autenticada), Kiarostami indaga, durante todo o filme, o que seria autêntico e veraz em contraponto àquilo tomado como artificial e falso ao apresentar um roteiro em espiral que polemiza o valor da cópia em obras de arte e se desdobra em camadas interpretativas. É o diretor Panahi quem nos oferece, em Isto não é um filme, uma síntese dos dois filmes anteriores: proibido de realizar filmes (veto por ele obedecido) e anunciando se tratar de um "documentário" - denominação pouco comum nos modos do realismo cinema iraniano -, o diretor é filmado e encena, em prisão domiciliar (que perdurou por dois meses e só foi encerrada após uma greve de fome), um dia completo de confinamento como forma de relatar as privações a ele impostas e, metonimicamente, ao próprio cinema.

Em seus documentários, Coutinho evoca diversos modos ficcionais para contar as histórias vividas pelos entrevistados - transformados em personagens - e desafiar as fronteiras entre reprodução e fabulação. Os filmes podem ser vistos como uma espécie de trilogia (ou reiteração) a respeito do cinema e de seus modos de realiza- ção, além de retomar a crítica ao conceito de representação. Encenados no ambiente de teatro, em Jogo de cena, composto apenas por personagens femininas, vemos a mistura entre histórias verídicas e inventadas, atrizes e mulheres anônimas, espontaneidade e indução. Os depoimentos são apresentados em cenário minimalista, no qual as mulheres sentam-se à frente de Coutinho, de costas para a plateia vazia, invertendo as posições normalmente vistas no teatro e questionando os limites da interpretação. Moscou, por sua vez, retrata os bastidores do grupo de teatro mineiro Galpão, ensaiando em um teatro vazio a peça "As três irmãs", de Tchekhov, jamais apresentada ao público.

Finalmente, As canções desenvolve uma premissa aparentemente simples: cada um dos entrevistados deve contar (e cantar) a história de uma música que tenha marcado sua vida. Mais uma vez o cenário é um teatro, mas o ponto de fuga situa-se nos fundos do palco, entre cortinas, lugar por onde entram e saem os personagens. Ao contrário de dicotomizar suas narrativas, tais documentários se movimentam nas imbricações entre fato/ relato, referencialidade/ficcionalidade, realidade/ fantasia. A exemplo dos filmes anteriores, essas imagens nos alertam, reiteradamente, para a precariedade na apreensão ou representação fidedigna da realidade, ressaltando a impossibilidade de objetivação dos relatos e a pregnância do processo tradutório que se impõe a qualquer discurso sempre que os artifícios da narrativa são acionados. Respondendo de modo contundente à tentativa de domesticação percebida em imagens que se pretendem referenciais, tais filmes reafirmam seu pacto ficcional com os espectadores, como se dissessem, paradoxalmente, isto é apenas um filme.

Nos interstícios de uma realidade oculta que pretende se fazer ver e de uma visibilidade englobante que pretende tudo mostrar, vemos desfilar imagens mais ou 
menos reais, mais ou menos verdadeiras, mas sempre engajadas na tensão entre visibilidade e invisibilidade dos sujeitos nelas representados, como nos filmes tratados a seguir.

\section{Contornos invisíveis de um outro docu- mentado}

Analisaremos no artigo articulações feitas por três documentários brasileiros recentes, exibidos em circuito comercial e que, privilegiando um discurso referencial e de caráter realista, apresentam como personagens sujeitos marcados por modos de vida diversos e, muitas vezes, por ocuparem posições periféricas em relação a papéis sociais tradicionalmente estabelecidos. O empenho realista interessa por operar um movimento de afirmação da marca dos sujeitos representados, aprovando-a como se ela fosse, no âmbito do filme e no âmbito da vida, exatamente como mostrada. Por outro lado, as fabulações neles contidas - especialmente por se tratarem de documentários - tornam-se contundentes pelo fato de estabelecerem relações diretas com a composição da imagem de um outro, ou seja: para além de sua vocação documental de se voltar ao outro, tais filmes tematizam também sua interferência na construção dessa imagem por meio dos personagens apresentados.

Desse modo, as invisibilidades sociais, frequentemente relatadas em documentários, são de fato problematizadas nesses filmes, que não apenas se contrapõem ao que normalmente é tornado visível - trazendo figuras divergentes -, mas problematizam os modos de fazê-lo, ampliando o campo do visível e autenticando, assim, novas políticas da representação dos sujeitos filmados. Sob essas premissas, trataremos a seguir dos filmes Elena (Petra Costa, 2013), Cidade cinza (Marcelo Mesquita e Guilherme Valiengo, 2013) e Olhe pra mim de novo (Kiko Goifman e Claudia Priscila, 2011).
Para além de semelhanças estilísticas - que se acentuam nos tempos atuais -, reportagem e documentário posicionam-se diferentemente em relação às formas de construção da representação e às relações desta com o imaginário social. Ao ressignificar os fatos para representá-los culturalmente, ainda que tenham como base os acontecimentos (ou atualidades), é de um processo de criação que se trata, inventando uma história por meio de fabulações narrativas. De distintos modos de dar a ver o outro, por meio de formas mais extremas ou mais domesticadas, espaços de visibilidades e invisibilidades apresentam-se nas telas da televisão e do cinema, apontando para diferentes concepções estéticas, temáticas, éticas, estilísticas e narrativas.

No caso dos programas telejornalísticos, a presença do repórter no local em que se passa a notícia e a importância da transmissão ao vivo, tornando-o, ao mesmo tempo, narrador e sujeito da ação, confirmam sua atuação como personagem da narrativa e representante do espectador (uma espécie de testemunha do testemunho atestado pelo jornalismo), colocando-se em seu lugar e construindo a cena como se o espectador estivesse nela presente. A realidade encenada, ou telerrealidade, insere-se nesse espaço de atuação que distancia as reportagens dos documentários. Estes, como afirmamos, não são apenas filmes de caráter informativo ou didático, mas reconstroem a realidade a partir de um ponto de vista subjetivo que se estabelece no intervalo entre cineasta e personagem, um "eu" e um "outro" colocados em relação.

Em vez de desenrolar a narrativa aos olhos do espectador, o documentarista, normalmente fora de quadro mas presente por meio dos enfoques buscados, tem como desafio ocupar o lugar de escuta do outro, mais do que tornar audível sua própria voz. Ao contrário de atuar como personagem, o sujeito que se inscreve nos 
documentários não se pretende uma representação fiel da pessoa, retratada em seu cotidiano, mas torna-se, nas palavras de Eduardo Coutinho, "a melhor versão daquela pessoa": "No cotidiano as pessoas são tão naturais quanto artificiais. Que processo a pessoa levou para atingir o seu natural? É a criação da mentira verdadeira. É óbvio que uma pessoa assume dez pessoas diferentes no seu cotidiano" (COUTINHO; XAVIER; FURTADO, 2005, p. 119). Ao deslocar o foco da legitimidade para a legitimação, o documentarista alcança, por meio do fingimento, o que há de mais singular no sujeito simulado nas imagens:

A respeito da relação entre pessoa e personagem, ocorre algo interessante. $\mathrm{Na}$ filmagem, encontro-me com uma pessoa durante uma hora, sem a conhecer de antemão, e às vezes nunca mais a vejo depois disso. E na montagem, durante meses, lido com ela como se fosse um personagem. Ela é, de certa forma, uma ficção, por isso a chamo de personagem, já que ela "inventou", numa hora de encontro, uma vida que nunca conheci. Se o filmo durante uma hora, ficam na edição final cinco ou sete minutos. Faço dela um concentrado daquilo que eu acho que é o melhor que ela possa ter (COUTINHO; XAVIER; FURTADO, 2005, p. 121).

De modo paradoxal, ao ausentar-se da tela o realizador nela deixa suas marcas, por meio dos encontros discursivos, e não presenciais, atestados pelas imagens da câmera, numa espécie de autoria partilhada em que, nos moldes da teoria da enunciação, instauram-se possibilidades de reversibilidade entre um "eu" e um "outro" que intercambiam lugares para que cada um possa ganhar voz e tomar corpo. Nas reportagens jornalísticas, ao contrário, o lugar do realizador é ocupado pelos repórteres. Mesmo que esses não direcionem a narrativa - ao contrário, o jornalismo apregoa a neutralidade do re- lato e produz, como efeito de sentido, o apagamento das marcas do enunciador -, sua presença física se faz sentir a cada passo, demarcando de modo mais incisivo os vieses da narrativa e unificando, ao menos na superfície, seu relato.

Ainda que ambos, reportagem e documentário, apresentem sujeitos concretos, histórias acontecidas e situações pertencentes ao mundo histórico - explicitando seu caráter referencial e testemunhal -, os documentários ocupam-se menos da busca pela verdade das pessoas e dos fatos retratados, e dedicam-se mais a interpretações sobre tais pessoas e fatos, elaborando suas narrativas a partir das informações e histórias de vida colhidas por meio das interações verbais com seus personagens. A problemática da objetividade e da autenticidade, certificadas pelo repórter que vivencia as histórias ao mesmo tempo em que as apresenta ao telespectador, não se coloca para o documentarista, que assume o caráter provisório de seu relato, tecido sempre a posteriori, em outro tempo e lugar que não os da própria ação. Como afirma Coutinho:

No documentário é preciso sair de si. (...) O documentário é isso: o encontro do cineasta com o mundo, geralmente socialmente diferentes e intermediados por uma câmera que lhe dá um poder, e esse jogo é fascinante. Portanto, o fundamental do documentário ou acontece no instante do encontro ou não acontece. E se não acontece, não tem filme. $E$ como você depende inteiramente do outro para que aconteça algo, é preciso se entregar para ver se acontece (COUTINHO; XAVIER; FURTADO, 2005, p. 121).

Estabelecemos metodologicamente duas formas pelas quais a questão da invisibilidade tem permeado a produção fílmica: o ímpeto de representá-la enquanto ausência e a visibilidade dada aos su- 
jeitos em situação de invisibilidade. No limite, há sempre algo de invisível que não poderá ser captado, do mesmo modo que, num embate com uma dimensão imponderável, a câmera aponta para sujeitos incluindo-os em sua invisibilidade positivada (representada pela presença de uma ausência) ou visibilidade indiferente (caso em que a própria indiferença se torna a marca). Estas marcas estão relacionadas aos tipos de vínculo estimulados na produção fílmica em negociação com a realidade (dos sujeitos e de onde se inserem).

Observamos a composição cênica em que esses sujeitos são mostrados (planos, enquadramentos e montagem), a perspectiva de um olhar organizador das cenas (identificado como aquele que concede o direito à visibilidade) e a possível relação entre os elementos visíveis e aqueles que dialogam com um espaço do nãodito que, como apontamos, faz-se presente na cena por meio dessa relação. Finalmente, argumentamos sobre como as cenas analisadas não precisam ser obscuras para que ocorra uma determinação de invisibilidade. Antes, a figura dos sujeitos engajados, em relação com outros sujeitos e objetos do entorno cênico, será a principal característica determinante de sua situação.

Elena (2013), dirigido por Petra Costa, é um documentário brasileiro aclamado em diversas premiações nacionais e internacionais. Interessa-nos,sobretudo, por lidar justamente com a falta de Elena, que será presentificada, durante o filme, com fragmentos de vídeos costurados como uma composição na memória. Outra relação de ausência-presença marca o filme: trata-se da implicação autoral de Petra Costa, a diretora, e sua ausência, para deixar que a memória da irmã fale. Além disso, Elena segue uma carreira artística que é referência em todo o filme - a dança, o teatro. A experiência artística da personagem é respondida com um filme documentário, na berlinda entre o referencial e o emaranhado poético da composição fílmica, articulando o relato a um tempo factual e ficcional.

Para além das anotações que podemos fazer na proposta anunciada do documentário, e que o inclui diretamente no debate sobre os limites entre visibilidade e invisibilidade, os elementos da composição fílmica desenham mais precisamente as nuances desse encontro. A trilha sonora desempenha um papel importante para situar o espectador no tempo da memória, e não no tempo presente de Elena, pois é a música que distancia o que se vê hoje da experiência factual passada. Ela conduz, no âmbito daquilo que nos é apresentado como imagem, um corpo que ser torna fluído, etéreo e de contornos dificilmente definidos. Desse modo, a presença de Elena pode ser novamente vivida, ainda que mediada pela fluidez da água, pelo etéreo da dança e pela borramento técnico possibilitado por vídeos amadores.

Elena viaja para Nova York com o mesmo sonho da mãe: ser atriz de cinema. Deixa para trás uma infância passada na clandestinidade durante a ditadura militar, e uma adolescência vivida entre peças de teatro e filmes caseiros. Também deixa Petra, sua irmã de 7 anos. Duas décadas mais tarde, Petra também se torna atriz e embarca para Nova York em busca de Elena. Tem apenas pistas: fitas de vídeo, recortes de jornais, diários e cartas. A qualquer momento, Petra espera encontrar Elena andando pelas ruas. Aos poucos, os traços das duas se confundem. Já não se sabe quem é uma e quem é a outra. No espaço entre o corpo invisível de Elena e a presentificação tornada visível por sua irmã, vemos materializar-se, de modo etéreo, os contornos do irrepresentável: trata-se do desaparecimento causado pela morte, já que esta encerra qualquer possibilidade de imagens referenciais, mesmo que se trate de um documentário em busca de seus sujeitos ou, mais do que isso, em busca dos limites de seu discurso. 

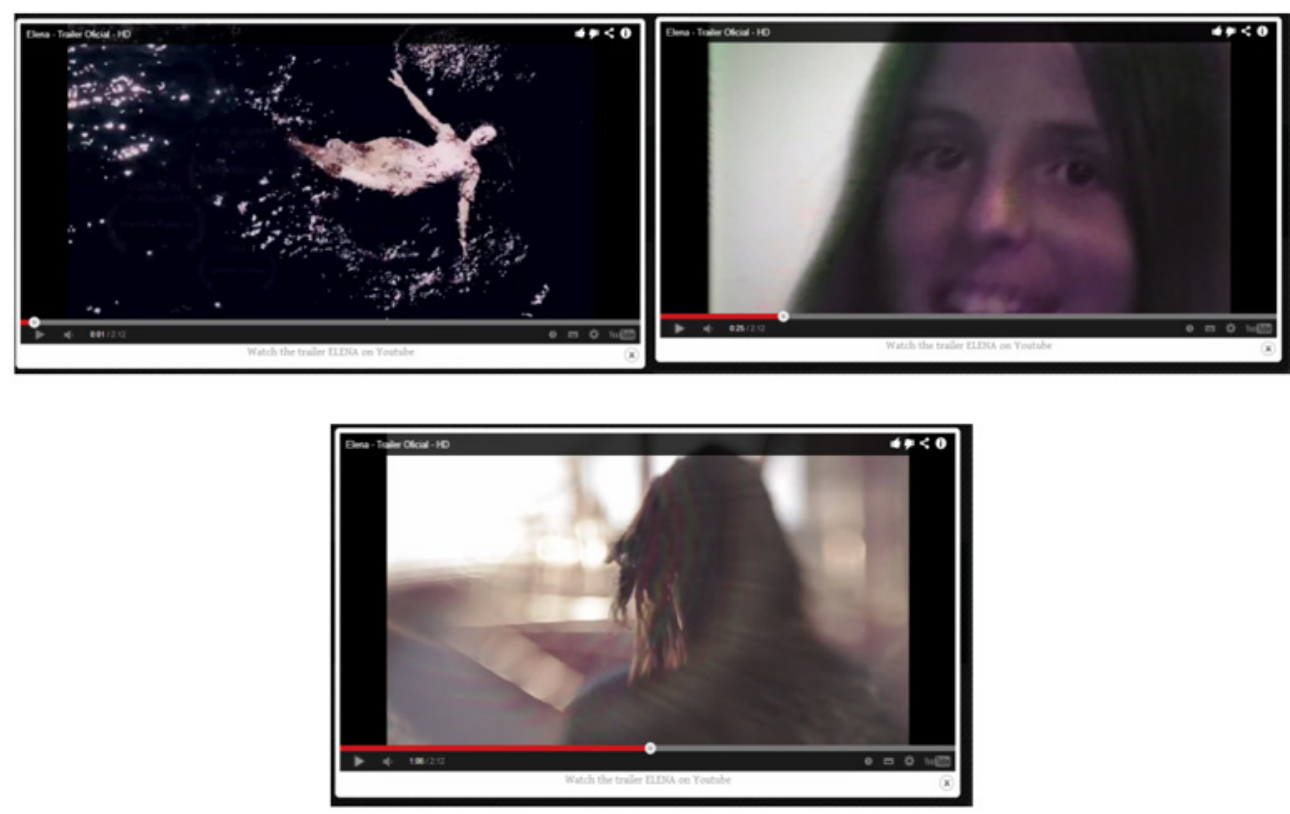

Cenas de Elena

O filme Elena articula a relação com o visível imergindo suas personagens em ambientes etéreos ou fluidos. A cena inicial mostra uma tomada do corpo feminino visto de cima, movendo-se como em uma dança na água. A horizontalidade da cena não nos remete tanto ao ambiente aquático que identificamos quanto a um movimento no ar, como se estivéssemos olhando para o céu. A movimentação da roupa soma-se àquela do corpo, contribuindo para o obscurecimento de contornos.A imagem causa um estranhamento por unir um corpo vestido à água, e o movimento lento da atriz também contribui para um estado semeIhante de não saber qual a referência exata da cena. Ainda não identificamos e não podemos reconhecer as mulheres, personagens femininas envolvidas na narrativa do filme. Estamos diante, simplesmente, de um corpo feminino flutuante, situando o espectador num tempo distinto - aquele da memória - e possibilitando uma aproximação afetiva, com tomadas poéticas e disruptivas, à narrativa do filme.

Numa segunda imagem, o ambiente aquático dá lugar a uma cena de impressões amadoras ou caseiras em que surge uma menina, centro das atenções, em close. A movimentação que se produz é mais rápida, a focalização da personagem menos segura e mais fugidia. Se na cena anterior ela nos escapava e se fazia invisível pela falta de reconhecimento, nessa notamos uma marca referencial, mas o fato ainda escapa ao foco. Temos um quadro pixelizado, o balanço incômodo das câmeras amadoras. Adiciona-se a isso, considerando a experiência do espectador, a distância temporal marcada pelo rosto e pelo sorriso de menina.No quadro seguinte, temos uma personagem já madura. Sendo ela a representação de um tempo atualizado (passagem de criança a adulta), mas não presente (a adulta vive somente na memória), a mulher aparece-nos de costas, afastando-se. Dessa forma, também escapa em sua invisibilidade. Uma vez mais, acompanhamos o borramento pela movimentação que se imprime na cena.

Nosso segundo exemplo é Cidade cinza (2013), com direção de Guilherme Valiengo e Marcelo Mesquita, que participou do festival de produção audiovisual "É tudo verdade". . O filme apresenta grafites feitos pelos artistas Os Gêmeos, Nunca e Nina, na cidade de São Paulo (SP), e que são torna- 
dos invisíveis pela decisão da prefeitura da cidade em eliminar o que considerava ser "poluição visual" (grafites, pichações, cartazes, outdoors, pôsteres, luminosos) por meio da repintura dos muros da metrópole. O documentário se monta, assim sobre uma disputa institucionalizada a respeito das cores que devem revestir a cidade: o colorido dos grafites ou seu recobrimento pela uniformização acinzentada.

O filme apresenta uma tomada panorâmica da cidade de São Paulo, marcando o adensamento da área construída e de sua lavagem cinza-concreto. O grafite é então recuperado como forma de reação à erupção do concreto, como uma marca visível nas paredes construídas. A relação com a invisibilidade, nesse caso, faz-se com o cinza que ele encobre, cor original de tudo o que é concreto. Os grafites reapresentados em cena produzem uma segunda pintura, que é aquela documentada pelo filme e mostrada ao espectador, trazendo os artistas como protagonistas da encenação, sobre os muros cinzas, de algo que antes estava ali e foi recoberto. Vemos os grafites à medida que vão sendo realizados: a justaposição de cenas con- trasta com o cinza que recobre acidade e para o qual ela havia retornado. Dessa forma, a passagem de uma cena a outra faz do espaço urbano um campo de batalhas simbólicas do visível, um embate entre representações. Onde os olhos poderiam ver uniformidade, há a marca de uma disputa que é,ao mesmo tempo, estética e política, sobre um território aparentemente indomado e coletivo, pertencente a cada um dos sujeitos que nele transitam.

O filme estabelece um contraponto visual entre a verticalidade da cidade, percebia na estrutura dos prédios, e a horizontalidade da execução dos grafites em seus muros. A ação em cena é executada por veículos representando a prefeitura da cidade, invadindo a paisagem e se postando na frente dos muros para o trabalho de recobrimento das pinturas. A partir dessa intervenção, ocorre um questionamento sobre o lugar da arte no espaço da cidade, em que percebemos, por um lado, a visibilidade de uma luta por assepsia sobre a qual está instaurado um desejo de cidade e, por outro, a "sujeira" dos grafites, intervenção artística que a transforma pervertidamente como se fosse um ruído na homogeneidade de suas cores.
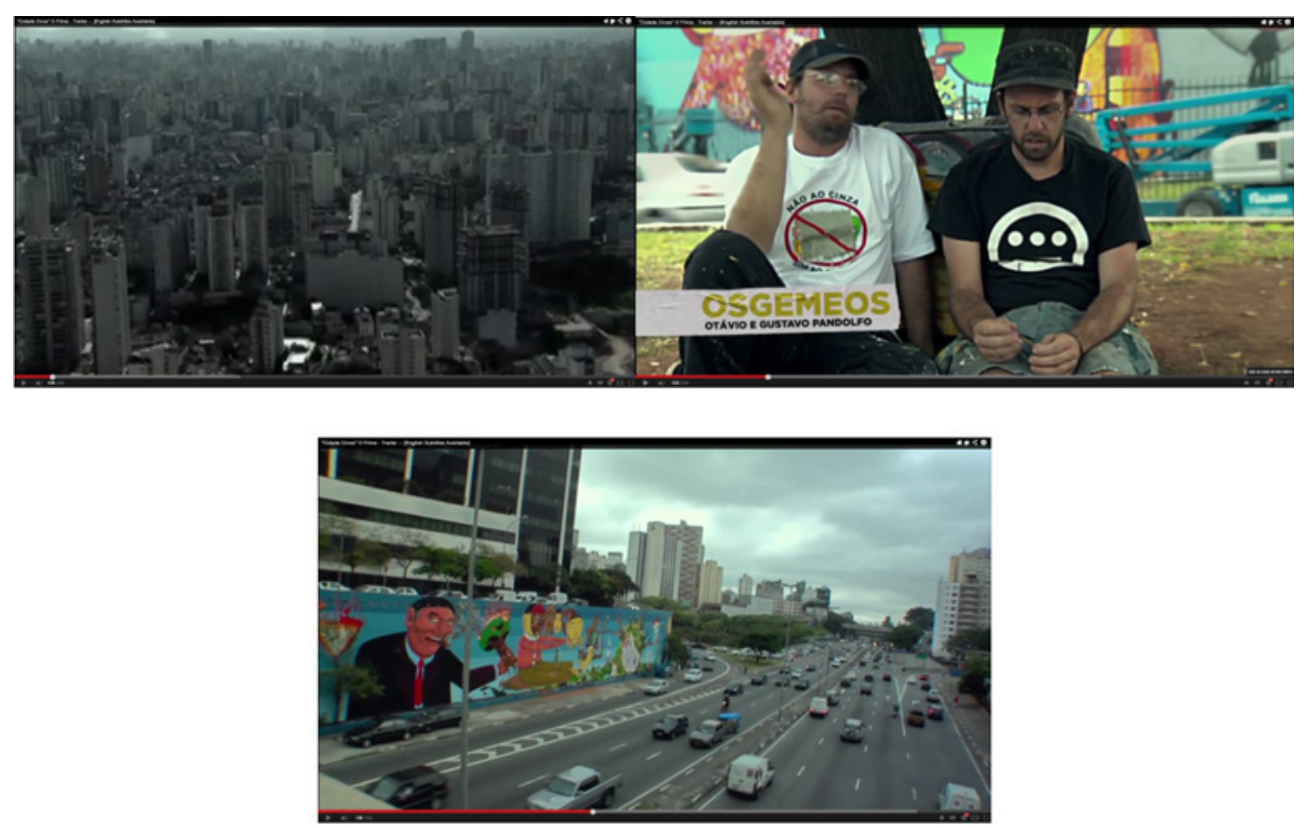

Cenas de Cidade cinza 
Parece-nos um compromisso do documentário, ou um código a ser aplicado a toda escrita fílmica, oferecer um quadro que represente a visão geral do tema numa imagem sintetizadora. No caso de Elena, era o corpo imerso dançante na água, oferecendo poucos elementos referenciais sobre um espaço-tempo. Já em Cidade cinza, a inauguração da narrativa é feita com a referência explícita à cidade de São Paulo em sua forte presença. Nem por isso deixamos de considerar que o primeiro quadro selecionado seja também,em certa medida, oceânico, extravasando seus limites ao fazer imaginar uma infinita extensão cinza para além dele.

Curiosamente, da mesma forma que notamos em Elena, temos uma perspectiva de olhar mais incomum, aquela em plongée ou contra-plongée. Esse posicionamento do olhar, somado ao do espectador, empodera-o com um lugar de ver ao mesmo tempo em que torna invisível o que não está captado no que seria uma tomada mais ampla. Outros quadros que se seguem procurarão recobrir tal falta, acionada na elaboração da narrativa imagética. Ao longo do documentário, o colorido do grafite ganha seu espaço em cena.

Em um outro quadro, a imagem está recortada, mas presente atrás dos artistas-grafiteiros em primeiro plano. Notemos que ele reproduz o modelo tradicional da reportagem informativa para a apresentação da fala das personagens. O efeito que se tem é o endosso àquele que fala, pelo que consideramos que este seja um lugar de invisibilidade e, desse modo, aberto para pessoas que estão tanto socialmente à margem (com sua atividade artística), quanto invisíveis atrás de suas próprias obras como artistas.

Na sequencia das imagens, vemos a verticalidade das construções cinzentas ser desafiada pela horizontalidade longilínea do muro grafitado. O espaço do muro cinza combinado com o asfalto, que não seria comumente notado, e a própria estrutura da cidade, ganha estatuto de espaço de arte. Cidade cinza mostra a atividade do grafite como uma iniciativa de ocupação do espaço invisível para a esfera do notável. Ao mesmo tempo, o movimento de atrair o olhar faz do muro grafitado um lugar de contenda entre o incômodo estímulo ao olhar ou seu apaziguamento monótono.

O terceiro filme é o documentário Olhe pra mim de novo (2011), definido como uma espécie de "filme de estrada" e dirigido por Kiko Goifman e Claudia Priscilla. Notemos que Goifman já havia dirigido os documentários 33 (2002) e Filmefobia (2008), entre outros, tratando de situações limítrofes no que diz respeito aos modos de construção de identidades periféricas e as formas instituídas de sua representação, como se pudesse, de algum modo, captar o inapreensível por meio de imagens extremas. No filme, o transexual Silvyio Luccio é retratado no cenário do sertão nordestino em que habita com sua esposa. Uma fala da personagem interpreta $\mathrm{o}$ ato de tirar a roupa como se este fosse um desvelamento, um deixar cair a máscara da visibilidade masculina que o protagonista sustenta. O título aponta para este mesmo movimento de duplo olhar, de retorno para verificar o que verdadeiramente se vê. A complexidade do filme reside, justamente, na incerteza que faz repousar a visão sobre um imaginário difuso e pouco marcado, ou melhor, recortado, filmado em cortes.

Nesse caso, para além da representação, trabalha-se a invisibilidade pela falta declarada do órgão sexual masculino. Ao mesmo tempo em que ele se faz presente na construção dos diálogos e da concatenação entre as cenas, 
Silvyio pede que outros ponham a mão em seu corpo para que possam verificar a ausência daquilo que todos pensavam que ele teria entre as pernas. $\mathrm{O}$ documentário resume essa situação, aparen- temente contraditória por oscilar entre o visível e o invisível, na equação "eu pensava que você era um homem que tinha desistido de ser homem e agora procura ser de novo".
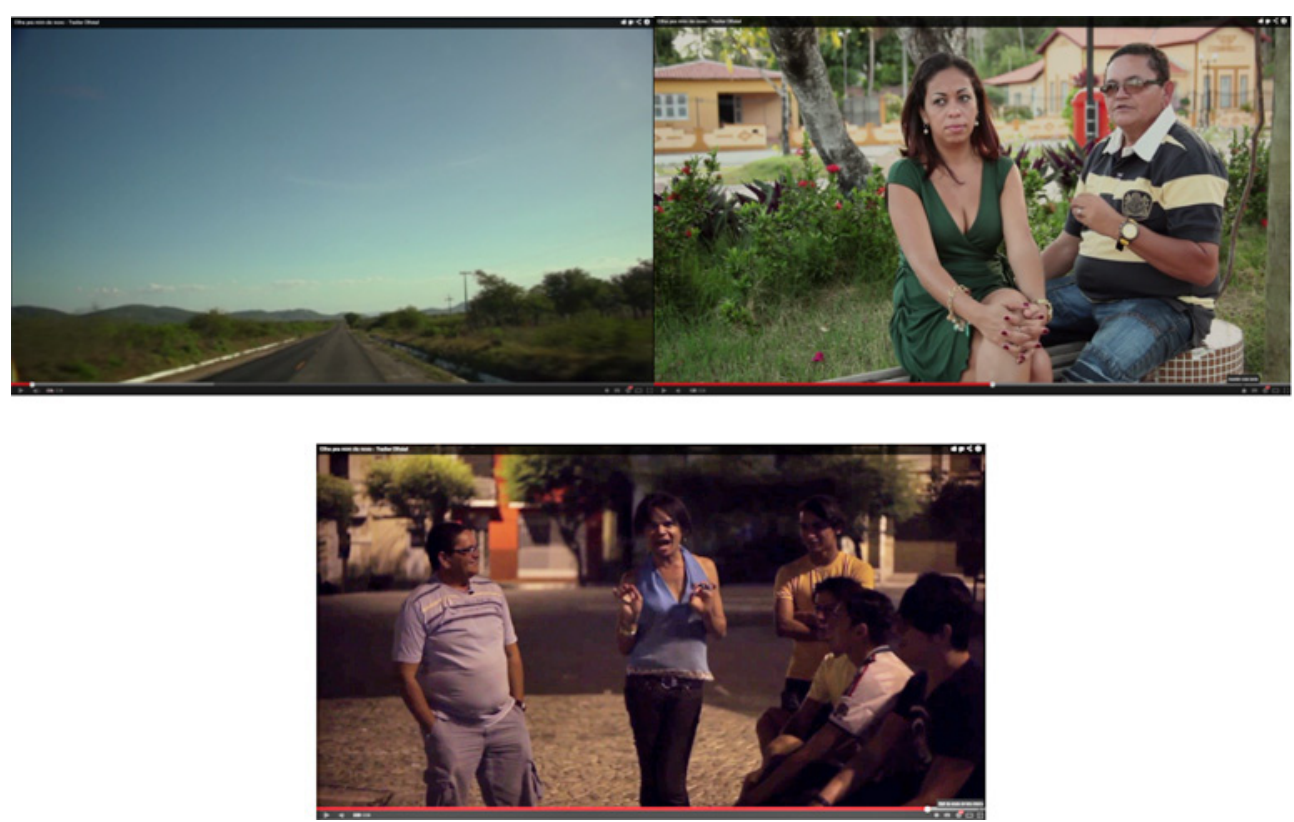

Cenas de Olhe para mim de novo

A cena em plano mais geral que marca este documentário é a imagem de uma estrada liberada para a circulação, mas sem outros veículos circulando. O que não está visível é o homem desejante de livre circulação. Há no horizonte o encaminhamento por uma busca, que entendemos como sendo uma busca de identidade. Um outro quadro apresenta o personagem em momento de fala, tornando-o visível dentro do cenário da cidade em que ele se encontra com sua companheira. Ele de pernas abertas, roupa vestida para ocultar; ela de pernas cruzadas, decote para mostrar.

Durante todo o documentário há uma clara tentativa de desestabilizar os limites entre os comportamentos esperados de acordo com os gêneros masculino ou feminino. Em um terceiro quadro, vemos uma personagem falando de si e de sua presença no mundo, dita para "incomodar". Ela fala à noite, sob sombras, esua atuação marca ainda o que podemos reconhecer como uma gesticulação feminina em um homossexual masculino.

Em Olhe pra mim de novo, a questão da invisibilidade está marcada pela apresentação dos espaços e das condições pelas quais a sexualidade pode ser socialmente expressa, manifestada e vivida. O filme traz à tona, para o âmbito do visível e para a luz do dia, o que pertenceria ao privado. Ao mesmo tempo, a 
privacidade está imbuída de um ímpeto de reconhecimento e aceitação públicos. O documentário circula entre essas duas esferas, transitando pelas estradas daquilo que estaria dentro, voltado para a intimidade, e daquilo que estaria fora, projetado para a exposição.

\section{Construção identitária: invisibilidades visíveis e circulação mercadológica}

Pretendemos, com os exemplos descritos, apresentar a relação entre o "um" e o "outro", espectador e personagem, por semelhança e identificação, ou por contraste e repulsa. Tal articulação se estabelece no campo visual e é própria do fazer documental por meio do ímpeto de ver o diferente. O debate, então, estende-se ao ponto em que entendemos o olhar como porta de entrada para um circuito de circulação que depende de uma identificação inicial com o objeto visto e de sua apropriação, oferecida como produto audiovisual.

De maneira mais abrangente, podemos dizer que a experiência identificada como artística e política passa pelos mesmos canais midiáticos que a possibilidade de consumo cultural. Mais, ainda, objetos de consumo complementam a mesma experiência na medida em que passam a ser a representação da experiência identitária mesma, uma vivência de sua certeza totalizante: "Os enunciadores das máquinas comunicacionais ritualizam a especialização estética da mercadoria, já que as atividades de leitura, audição, televisão e imersão convocam o receptor a vivenciar experiências multissensoriais, voltadas à construção de uma vida desejável, construídas com apoio dos especialistas" (PRADO, 2013, p. 30).

Nesse sentido, a apresentação de personagens com identidades minoritárias se dá de forma desejavelmente es- tética, apelativa, circulante e, associado a isso, vendável. A dimensão política do olhar, assim, está marcada por uma lógica do aceitável como limite cultural em favor de satisfazer desígnios do imaginário: "Em vez de politizar a existência, os agentes ficam sem cessar fazendo indagações e ouvindo os enunciadores dos dispositivos, de modo a construir suas identidades e chegar à plenitude imaginária" (PRADO, 2013, p. 43).

De todo modo, não podemos assumir que, com isso, tal dimensão política do olhar esteja sufocada, visto que os limites do que é culturalmente desejável tem a fluidez característica das formações discursivas. O que reforçamos ao analisar os exemplos de documentários nacionais recentes é que há um limiar desafiador sobre o qual eles operam. E o fazem sob uma visibilidade instituída, conformando-se nela ao mesmo tempo em que a desafiam. Identidades minoritárias ganham, assim, em presença, mas desaparecem na invisibilidade de tudo aquilo que não cabe na ordem do visível. O exercício do documentário, dessa forma, instaura uma distância entre o espectador e o outro que ele aborda por meio do olhar, assegurado pela mediação da tela. Ao mesmo tempo, recobre tal distância, na medida em que transporta o espectador para dentro da cena. Ele é colocado, assim, no que podemos chamar de uma posição de consumidor escópico, aproximando-se do outro e dele se afastando.

Acreditamos que, dessa forma, a prática documental oferece um apelo à veracidade dos fatos que estão sendo retratados e uma forma de engajamento por meio deles. O espectador é chamado a se posicionar politicamente diante de uma dita verdade. A aderência a essa visibilidade, e seu consumo, revela-nos um ato de fé assentado sobre a articulação dos fatos proposta pelas imagens. 
Quanto mais referenciada a imagem do outro, mais a sensação de estranhamento pode ser avivada enquanto opção estética e política, dosada pela aceitabilidade do olhar de um público. Quanto mais poético, menos o filme estará comprometido com a implicação de uma resposta do espectador a uma situação descrita. Temos duas propostas diversas para formas de consumo documental, uma delas apelando para a fruição e outra para o engajamento, uma como mecanismo de participação passiva e outra como chamado à participação ativa, ainda que em ambas ocorram diferentes graus de participação.

Rancière refere-se à imagem que causa esse tipo de estranhamento como uma "imagem intolerável", citando seu aspecto de demonstração "da exibição da verdade do espetáculo como uma forma ainda mais intolerável de seu reinado, pois sob a máscara da indignação, ela oferecia ao olhar dos observadores não só a bela aparência, mas também a realidade abjeta" (RANCIĖRE, 2012, p. 83). O autor se questiona sobre a validade estética e política da circulação de tais imagens, se por mera curiosidade perversa ou se por ímpeto revolucionário. Se considerarmos que a intolerância pode ser entendida como reação à proximidade, àquilo que antes distante se torna visível de maneira não domesticada, de alguma forma a aproximação promovida pelo documentário pode provocar reações passionais.

O movimento de retorno na circulação dessas cenas se faz justamente pela via do abjeto. Se uma imagem é entendida como tolerável, ela tem sua circulação e consumo abertos pelas vias de um senso comum, pautada pelos códigos instituídos de visibilidade. Se, de outro modo, ela é considerada intolerável, ainda assim o chamado para a aproximação em relação ao outro cumpre sua vocação de circular. O trajeto do grotesco se revela como o avesso do mesmo regime de visibilidade no qual estão englobados um e outro. Ambos são retratados a partir da mesma materialidade audiovisual, dependente de uma adequação a um certo código de construção fílmica.Devemos considerara ação do documentário como um relevo sobre os sujeitos que toca. Ele os insere no âmbito do visível, congelando-os identitariamente, ao mesmo tempo em que promove seu reconhecimento e ressignificação. O aspecto documental faz também com que personagens concretos possam perceber sua inserção e reconhecimento social como transformados para além da esfera fílmica.

Apontamos para esse aspecto sem que, necessariamente, estejamos estabelecendo juízos de valor em relação a ele, especialmente nos casos de filmes sobre identidades minoritárias. Não o fazemos, pois identificamos uma camada a mais na qual engendrar a possibilidade de circulação fílmica, qual seja, o lastro representacional de qualquer produção na cultura. As identidades alçadas para o âmbito do visível não se iniciam com o ato do documentário, mas dependem de prévios atos documentais de outra ordem. A extensão da grande tela que abarca os sujeitos tornados visíveis em filmes é cambiante e acompanha a marca social que se interpõe - e, como temos dito, caracteriza - a circulação de identidades minoritárias.

Devemos apontar que certos documentários rasgam a cena de representações estabelecidas e se colocam como um ato criativo em direção ao novo, tendo aceitação e tolerância mais arriscada, à medida que o terreno de sua instauração social é da mesma forma incerto: "Trata-se realmente de afe- 
tos que embaralham as falsas evidências dos esquemas estratégicos; são disposições do corpo e do espírito em que o olho não sabe de antemão o que está vendo, e o pensamento não sabe o que deve fazer com aquilo" (RANCIÈRE, 2012, p. 101).Podemos tratar, assim, de uma circulação afetiva da novidade documentada. Se por um lado ela representa um risco, por outro resolve a aposta por reconhecimento de identidades ainda não estabilizadas, caracterizando a circulação de filmes baseada na identificação afetiva como detentora de uma implicação estética e política.

Nos exemplos apresentados, há uma profanação dos objetos tornados visíveis - a morte, a arte, o corpo - por meio de sua concretização em cena. Ao mesmo tempo, a possibilidade de que parte deles não seja reconhecível, sendo recoberta por um tão determinado e central ímpeto de invisibilidade, faz movimentar a dinâmica fílmica.Entendemos, assim, que mais do que tornar visível aquilo que comumente não chega à cena, está na base do fazer documental a tentativa de tomada sobre um objeto fugidio à constituição cênica, que, por isso mesmo,nem pode oferecer-se por completo, nem a própria cena pode sobreviver sem obscurecer um desejo por totalidade.

Fizemos um percurso em três tempos para a análise dos filmes: retomamos a vocação referencial do documentário, instauramos a polêmica em relação à tomada documental tratando da questão da captura do outro e, finalmente, procuramos desenhar as vias de escape desta lógica da cena instituída apresentando formas da (in)visibilidade documentada.Ainda que a perspectiva tradicional do documentário procure filiar-se ao registro do verdadeiro, há em filmes recentes uma presença forte e constante da ficcionalização do relato, seja por meio de narrativas de busca ou aquelas tidas como autorreferenciais. Esse ímpeto está ligado, como o entendemos, à forma de percorrer a distância entre um "eu" e um "outro", não apenas em relação ao realizador dos filmes, mas também ao público, que se soma àqueles que documentam uma parcela da realidade, e também aos outros que compõem recortadamente a cena e nela se fazem.

Nesse primeiro tempo, há uma latente necessidade de recobrir a distância entre ambos num desejo de reparação narrativa, e o documentário o faz elevando traços de uma diferença. Não anotamos se tal diferença é considerada positiva ou negativa, mas destacamos sua condição de ser algo de interesse para ser visto. Há sempre, dessa forma, um olhar que marca o outro e o insere na ordem do visível. Ao mesmo tempo, como afirmamos, o outro se apresenta e se instaura a partir de sua entrada em cena. Desse modo, há sempre um momento que aponta para a questão da invisibilidade, inclusive e especialmente nos casos analisados à guisa de demonstração. Ao documentar, torna-se visível um outro de alguma forma distante, seja espacialmente, temporalmente ou, ainda, psicologicamente. Ou seja, outrem que não estava visível a olho nu no convívio cotidiano presentifica-se segundo a perspectiva daquele que reporta e, ao fazê-lo, aponta também para o lugar de sua invisibilidade. Novos atores sociais são postos em cena de modo mais ou menos disciplinado, ou como sujeitos enquadrados em regimes de visibilidades vigentes, ou como sujeitos em quadro que ampliam as políticas da representação usuais.

O segundo tempo do endereçamento à invisibilidade é a apresentação desse outro numa cena em que tal invisibilidade vem à tona, muitas vezes 
tematizada como ideia central do próprio documentário. Nesse sentido, atribui-se a missão de fazer ver o que estava obscurecido ou que não pode ser facilmente feito imagem, como no caso de documentários que tratam de identidades minoritárias ou de temas socialmente ignorados. Nesses casos, a presença do outro na cena é assumida de forma positivada, como movimento afirmativo de inclusão. Temos, assim, um processo criativo de tradução da questão do outro-personagem em formato de discurso audiovisual. Tal criação apresenta um desafio que tem, de um lado, a possibilidade de evidenciar o outro e, ao mesmo tempo,o risco de aprisioná-lo nas escolhas cênicas. Assim, documentários são polêmicos em seus discursos e escolhas éticas, estéticas e políticas.

Tal processo pode ser identificado tanto na construção da narração, como da articulação imagética. Se a narração pode apontar caminhos, ressaltando com palavras o que é visto, as imagens apelam para os olhos e conduzem o espectador para dentro da cena. É nesse sentido que devemos ressaltar um terceiro e último aspecto dos documentários em relação à questão da invisibilidade. A marca da presença do outro em cena é atestado de sua ausência e, de certa forma, o contrário também é válido: a ausência do outro em cena é seu nível de máxima presença. Ou seja, a documentação audiovisual sobre o outro é um processo de criação narrativa e sua presença é interferida pela associação com outros objetos em cena, que concorrem para construí-lo ou desmontá-lo. Assim, muitas vezes ao tentar reportar o outro, tornando-o visível, colocamo-lo numa posição de invisibilidade. Ao mesmo tempo, a latência de sua representação pode se tornar sua maior possibilidade de inteireza, como numa cena em que um personagem não está presente, mas seus efeitos visíveis se fazem sentir.

Os processos de invisibilidade, portanto, são fundantes na criação documental, tanto na aproximação com o outro por meio de temáticas específicas, como na inserção lógica de cenas que articulam os discursos audiovisuais: "É a voz de um corpo que transforma um acontecimento sensível em outro, esforçando-se por nos fazer 'ver' o que ele viu, por nos fazer ver o que ele nos disse" (RANCIÈRE, 2012, p. 92). Nessas duas perspectivas, podemos dizer que a invisibilidade torna plástica e maleável a composição cênica, sendo a principal responsável pela estruturação de uma dinâmica fílmica aberta a diferentes modos de representação e a novas formas de visibilidade.

\section{Bibliografia}

AUFDERHEIDE, Patricia. Documentary film: a very short introduction. Oxford: Oxford University Press, 2007.

AUMONT, Jacques. et al. A estética do filme. Campinas, SP: Papirus, 1995.

BAKHTIN, Mikhail. A cultura popular na Idade Média e no Renascimento. São Paulo: Hucitec, 1987.

BURKE, Peter. Testemunha ocular: história e imagem. Bauru: EDUSC, 2004.

CASTRO, Gisela. (In)Comunicação, consumo e sociabilidade na cena urbana: breve reflexão a partir do cinema. Revista Rumores. Vol. 7, n. 14, julho-dezembro de 2013.

COUTINHO, Eduardo; XAVIER, Ismail; FURTADO, J. O sujeito (extra)ordinário. In: MOURÃO, Maria Dora; LABAKI, Amir (orgs.). O cinema do real. São Paulo: Cosac Naify, 2005.

DE CERTEAU, Michel. A invenção do cotidia- 
no. Artes de fazer. Vol. 1. 2. ed. Petrópolis, RJ: Vozes, 1996.

ECO, Umberto. Seis passeios pelos bosques da ficção. São Paulo: Companhia das Letras, 1994.

FIGUEIREDO, Vera Lúcia Follain. Fronteiras invisíveis: o intelectual, o outro próximo e a estetização da política. XXI Encontro da Associação Nacional dos Programas de Pós- Graduação em Comunicação. Universidade Federal de Juiz de Fora, 2012.

GEERTZ, Clifford. Obras e vidas. O antropólogo como autor. 2. ed. Rio de Janeiro: UFRJ: 2005.

METZ, Christian. A significação no cinema. São Paulo: Perspectiva, 1972.

NICHOLS, Bill. Representing reality. Bloomington /Indianápolis: Indiana: University Press, 1991.

PRADO, José Luiz Aidar. Convocações biopolíticas dos dispositvos comunicacionais. São Paulo: Educ/Fapesp, 2013.

RANCIĖRE, Jacques. O desentendimento: política e filosofia. São Paulo: Editora 34, 1996.

O espectador emancipado. São Paulo: Martins Fontes, 2012.

A partilha do sensível. São Paulo:

Editora 34, 2005.

SOARES, Rosana de Lima. De convergências e hibridismos: remixagens e pilhagens em filmes de bordas. Revista MATRIZes. Ano 5, no 1, jul.-dez. 2011, p. 137-154.

WINSTON, Brian. A maldição do "jornalístico" na era digital. In: MOURÃO, Maria Dora; LABAKI, Amir. (orgs.). O cinema do real. São Paulo: Cosac Naify, 2005.

XAVIER, Ismail. O discurso cinematográfico. Rio de Janeiro: Paz e Terra, 1984.
1 Doutora em Ciências da Comunicação pela ECA-USP. Professora no Departamento de Jornalismo e Editoração e no Programa de Pós-Graduação em Meios e Processos Audiovisuais dessa mesma Escola, realizou pesquisa de pós-doutorado (2013-14) no King's College Brazil Institute (Londres/Inglaterra). É pesquisadora do MidiAto - Grupo de Estudos de Linguagem: Práticas Midiáticas e autora de Margens da comunicação: discurso e mídias (São Paulo, Annablume, 2009), além de diversos artigos publicados em livros e revistas acadêmicas. E-mail: rolima@usp.br.

2 Doutora em Ciências da Comunicação pela Escola de Comunicações e Artes da Universidade de São Paulo (2011), onde atualmente é pós-doutoranda (bolsista Fapesp) estudando processos de interdição discursiva nos mídia. Mestre pela mesma Escola (2006) com a dissertação O traçado da luz: um estudo da sintaxe em reportagens televisivas. É pesquisadora do MidiAto - Grupo de Estudos de Linguagem: Práticas Midiáticas. E-mail: andrealimberto@gmail.com.

3 Para informações e críticas dos filmes, ver site www. adorocinema.com.br. Acesso em 11/02/2012.

4 Festival internacional de documentários, reunindo importantes obras. Realizado anualmente, encontra-se em sua décima nona edição. Mais informações em: http://etudoverdade.com.br. Acessado em 25 mar. 2014. 